\title{
Mean Cell Density
}

National Cancer Institute

\section{Source}

National Cancer Institute. Mean Cell Density. NCI Thesaurus. Code C120712.

The arithmetic mean of a range of values that describe the cell density of an entity. 